\title{
DINAMIKA GRUPE SA STUDENTIMA ŠPANSKOG KAO NASLEDNOG, STRANOG I MATERNJEG JEZIKA**
}

Potrebe i pristupi kod podučavanja naslednih govornika su drugačije nego kod nastave stranog jezika, međutim, kako toj oblasti nije posvećeno dovoljno pažnje, nisu retke situacije da nasledni govornici španski jezik u formalnom kontekstu uče u mešovitim grupama zajedno sa stranim govornicima, a u nekim okolnostima i sa maternjim govornicima. Istraživački deo ovog rada sastoji se iz analize upitnika o učenju u mešovitim grupama i odnosu između pomenute tri različite grupacije učenika. Na upitnik su odgovarali studenti hispanistike sa tri nemačka univerziteta, gde su grupe izrazito mešovite usled velikog broja hispanskih iseljenika u zemlji. Istraživanje je potkrepljeno intervjuom sa lektorkom T.D. sa katedre za romanistiku na Univerzitetu Humbolt o radu studenata u mešovitim grupama. Rezultati istraživanja su pokazali da učenje u mešovitim grupama ima višestruke prednosti i malobrojna ograničenja po studente koji su toga svesni i ne bi odabrali da uče španski jezik u uobičajenim okolnostima, drugačijim od onoga na šta su navikli.

Ključne reči: nasledni govornici, učenici španskog kao stranog jezika, maternji govornici, nastava španskog jezika, nastava u mešovitim grupama.

\footnotetext{
* andjelagasic@gmail.com

** Ovaj rad je nastao na osnovu istraživanja koje je sprovedeno u svrhu pripreme master rada „Dinamika između studenata španskog kao maternjeg, stranog i naslednog jezika" koji je odbranjen na Filološkom fakultetu Univerziteta u Beogradu u julu 2018. godine, mentor prof. dr Ana Jovanović.
} 


\section{Uvod}

Nasledni jezik je specifična tvorevina koja ima sličnosti kako sa jezikom maternjih govornika tako i sa načinom izražavanja nematernjih govornika. Za nasledni jezik (u užem smislu) se može reći da je neka vrsta maternjeg jezika jer se oba usvajaju hronološki kao prvi ali se, pak, nasledni jezik usvaja u neuobičajenom okruženju gde jezik porodice nije isti kao i većinski. Dakle, nasledni jezik je usvojen spontano u prvim godinama života usled izloženosti mahom usmenom inputu (Jovanović, Vučina Simović 2012: 385). S druge strane, ima i sličnosti sa usvajanjem drugog (stranog) jezika jer se jezička kompetencija vidno razlikuje i varira od govornika do govornika, prisutne su greške kako u gramatici tako i u korišćenju leksike, jer je neki drugi jezik ovim govornicima dominantan.

Pored ovih sličnosti, razlike su više nego uočljive. Bugarski (2003: 117) daje jasnu distinkciju između maternjeg (prvog) i naslednog jezika, pozivajući se na tvrdnju da se "maternji jezik ne može ne znati“. Naime, deci i potomcima u migrantskim grupama koji slabo govore jezik svojih predaka (čak i roditelja), a kao prvi jezik usvajaju jezik zemlje gde su rođeni i/ili gde odrastaju, maternji jezik ne može biti taj jezik predaka. Njihov prvi ili maternji jezik je onaj koji su hronološki prvi naučili i kojim su okruženi, dok jezik predaka nosi upravo naziv - nasledni. Zatim, nasledni govornici nisu izloženi jeziku neprekidno i dovoljno dugo, te nemaju iste gramatičke i sociopragmatičke kompetencije poput maternjih govornika u užem smislu (Akosta Korte 2009: 133).

Nasledni jezik se razlikuje i od drugog ili stranog jezika jer se izgovor usvaja spontano i u tom segmentu se ne javljaju ozbiljniji problemi i poteškoće. Takođe se ne usvaja u kasnijem periodu života, kao što je to slučaj sa drugim jezikom, niti se, makar u početku, uči u sklopu formalnog obrazovanja, što znači da mnogi nasledni govornici poznaju samo neformalni jezik koji usvajaju u okviru porodice (Akosta Korte 2009: 133-134). Dakle, jedna od ključnih razlika između naslednog i stranog jezika jeste to što usvajanje naslednog jezika počinje u kući i među porodicom, dok strani jezik počinje da se usvaja, barem u prvi mah, u učionici (UCLA 2001: 8), te 
je uopšteno pravilo da se on zbog toga usvaja sporo (Kondo-Braun 2005: 574). Upravo to početno usvajanje naslednog jezika pretežno usmenim putem rezultuje boljom kompetencijom u usmenoj komunikaciji, odnosno slabije razvijenim veštinama pisanja kod njegovih govornika (Jovanović, Vučina Simović 2012: 385).

Nastava španskog kao naslednog jezika je složeno pitanje jer, uprkos želji govornika za učenjem, problematika često nije shvaćena dovoljno ozbiljno. S jedne strane, u mnogim slučajevima su jedini dostupni kursevi oni namenjeni učenicima španskog kao stranog jezika, dok, suprotno tome, različite institucije nude kurseve osmišljene za izvorne govornike koji se ne mogu smatrati korisnicima naslednog jezika (Akosta Korte 2009: 131). Shodno tome, različiti su razlozi zbog kojih dolazi do formiranja mešovitih grupa za učenje španskog jezika gde su prisutni nasledni, strani, a u nekim slučajevima i maternji govornici. To, dakle, može biti nepostojanje kurseva namenjenih isključivo naslednim govornicima, zatim bojazan ovih učenika da pohađaju takve kurseve jer smatraju da njihov nivo nije dovoljno visok (Potovski 2002: 40), potom osnivanje odeljenja i grupa od strane španskog Ministarstva prosvete (Kraljevski Dekret 1027/1993). Jedan od ne tako retkih oblika učenja jezika u mešovitoj grupi jesu i časovi španskog jezika i kulture kao sastavni deo studija hispanistike u različitim zemljama gde su prisutni strani, nasledni, ali i izvorni govornici koji dolaze sa namerom da studiraju i ostanu da rade u toj zemlji (kao što je to slučaj npr. sa Nemačkom).

Ovaj rad se bavi učenjem španskog jezika u mešovitim grupama gde su prisutni strani, nasledni, a u nekim slučajevima i maternji govornici, kao i dinamikom između ovih različitih grupa. U nastavku predstavljamo teorijski okvir u kome objašnjavamo kakvi su rezultati dosadašnjih istraživanja na temu učenja španskog jezika u mešovitim grupama i parovima. Potom predstavljamo empirijsko istraživanje koje se sastoji iz ankete sprovedene među studentima hispanistike sa tri nemačka univerziteta i intervjua sa lektorkom sa jednog od tih univerziteta. 


\section{Učenje španskog jezika u mešovitim grupama}

Do danas su sprovedena različita istraživanja na temu mešovitih grupa za učenje španskog jezika, pre svega u kombinaciji naslednih govornika i učenika španskog kao stranog jezika (SJ) (npr. Potovski 2002, Bouls 2009 i 2011, Dones Erera 2015, Burgo 2016). Manji broj radova (npr. Edstrom 2007) ovu temu je obogatio prisustvom maternjih govornika, i u njima su analizirani stavovi pripadnika ove tri različite kategorije prema učenju španskog jezika u heterogenoj grupi. Većina navedenih istraživanja kao nedostatak ima mali broj ispitanika, što je, međutim, u nekima od njih nadomešteno dodatnim intervjuima sa učenicima.

Dones Erera (2015) je sprovela istraživanje među učenicima početnog nivoa na kursu španskog jezika na jednom univerzitetu na jugozapadu SAD u vezi sa stavom učenika prema mešovitoj grupi u kojoj su pohađali nastavu. Ovo istraživanje je specifično po tome što ispitanici pohađaju kurs na početnom nivou, dok je većina drugih analiza fokusirana na studente naprednijih nivoa. U anketi su učestvovala 44 studenta od kojih je petnaestoro za sebe reklo da su nasledni govornici, dok se njih 29 izjasnilo kao nenasledni govornici. Istraživanje je pokazalo da učenici generalno imaju pozitivan stav prema nastavi u mešovitoj grupi, te da postoji niz prednosti koje ovakav spoj ima na obe grupe (kao što je uzajamna pomoć ili učenje o kulturi naslednih govornika), a da su mane ovakvog učenja malobrojne. Nasledni govornici nisu nestrpljivi kada kolege kojima je španski SJ treba nešto da kažu na španskom jeziku, niti je ovima neprijatno da pričaju pred naslednim govornicima. Ipak, pripadnici obe grupe bi radije odabrali da uče jezik u razdvojenim grupama, gde su prisutni samo učenici iz njihove „kategorije“. Istraživanje je, takođe, pokazalo da nasledni govornici smatraju svoje veštine usmene recepcije i produkcije razvijenijim od umeća u pisanju i čitanju, upravo zbog toga što su njih sticali i pre formalnog učenja. $\mathrm{S}$ druge strane, nenasledni govornici imaju razvijenije receptivne sposobnosti (veštine čitanja i slušanja).

Edstrom (2007) je istraživala stavove naslednih, maternjih i stranih učenika u mešovitoj grupi učenja višeg nivoa španskog je- 
zika na univerzitetu. Od 16 intervjuisanih i anketiranih ispitanika, dvoje su se izjasnili kao nasledni govornici, četvoro kao nematernji i desetoro kao maternji govornici. Mana ovog istraživanja jeste nedovoljan broj ispitanika te se kvantitativni podaci ne mogu generalizovati, ali je prednost u intervjuima koji su rađeni sa svakim studentom ponaosob, pa se iz njihovih odgovora mogu izvesti određeni zaključci. I u ovom istraživanju studenti uočavaju više prednosti nego mana heterogenih grupa. Neizvorni govornici su u intervjuima kao prednosti učenja jezika sa maternjim i naslednim govornicima istakli izloženost autentičnom jeziku i poboljšanje usmene recepcije, zatim kontakt sa različitim dijalektima i mogućnost da vežbaju španski jezik razgovarajući sa maternjim govornicima. Takođe su objasnili da u takvim okolnostima učenja obogaćuju svest o kulturi drugih naroda i da im to povećava motivaciju za napredovanjem. Istakli su još i da je većina maternjih i naslednih govornika voljna da im pomogne i odgovori na pitanja i nedoumice koje imaju. $\mathrm{S}$ druge strane, i maternji i nasledni govornici vide prednosti rada $\mathrm{u}$ mešovitoj grupi, na primer, jer se upoznaju sa kulturom neizvornih govornika. Svi maternji i nasledni govornici osim jednog izjasnili su se da su jednako srećni kada rade i sa nematernjim i sa naslednim ili maternjim govornicima. Oni su istakli i da cene sposobnost nematernjih govornika za objašnjavanje gramatičkih pravila i poznavanje gramatičke terminologije i da im to, kao budućim profesorima, dosta pomaže jer usvajaju drugu, „nematernju“ perspektivu prema jeziku. U istom istraživanju, ispitanici kojima je španski maternji jezik izjasnili su se da su im časovi ponekad prelaki, dok su nematernji govornici sa zadovoljstvom prihvatili činjenicu da se na časovima govori isključivo španski jezik, a negodovali kada im se nasledni govornici iz njihove grupe obraćaju na engleskom. Na kraju, čak i oni koji su na početku izrazili negativan stav prema mešovitoj grupi u kojoj uče, pronašli su i istakli neku prednost takvog rada. Još jedno novije istraživanje (Burgo 2016) ima sličnu koncepciju jer su rezultati takođe dobijeni na osnovu ankete i intervjua manjeg broja učenika (20), a razlika u odnosu na istraživanje koje je sprovela Edstrom (2007) jeste u tome što su ispitanici samo govornici kojima je španski SJ i fokus je na njihovim stavovima u vezi 
sa mešovitom grupom, zajedno sa naslednim govornicima. Među pozitivnim stavovima prema prisustvu naslednih govornika koje je ovo istraživanje potvrdilo izdvajaju su dobar uticaj na veštine slušanja, bolje poznavanje različitih dijalekata i činjenica da razgovor sa naslednim govornicima utiče na poboljšanje španskog jezika kod stranih govornika. Ovo istraživanje je, za razliku od prethodna dva, pokazalo da se učenici koji su strani govornici osećaju neprijatno kada treba da govore pred naslednim govornicima (Burgo 2016).

Poput govornika kojima je španski SJ, i nasledni govornici umeju da budu nesigurni u svoje znanje jezika, pogotovu u kontaktu sa monolingvalnim govornicima maternjeg jezika, kada se pokazuju kao nedovoljno samouvereni i boje se da govore jer misle da njihov španski nije dovoljno dobar, što može biti podstaknuto i društvenim razlikama. S druge strane, reakcije pri interakciji sa nematernjim govornicima su mahom suprotne jer nasledni govornici (uglavnom) imaju viši nivo jezičke kompetencije, mogu da pomognu svojim kolegama kod različitih pitanja, pa sve to doprinosi razvijanju njihovog samopouzdanja što se tiče jezika (Blejk i Zajzik 2003: 540).

Međutim, prema istraživanju Potovski (2002), nasledni govornici španskog jezika se i u grupama sa učenicima španskog kao SJ susreću sa nekoliko problema. Njima je neugodno zbog visokih očekivanja profesora i ostalih učenika iz grupe po pitanju njihovog znanja španskog jezika, a takođe se osećaju podređenima u odnosu na učenike kojima je španski SJ jer su oni imali kontakta sa standardnim varijetetom španskog i upoznati su sa lingvističkom terminologijom. Nasledni govornici takođe lošije od stranih govornika podnose kritiku profesora jer se za učenike stranog jezika podrazumeva da će biti ispravljani, dok kod naslednih govornika ispravljanje ukazuje na to da njihov španski nije standardni varijetet i usko je vezano za njihovu „ličnu i kulturnu istoriju“ (Potovski 2002: 40). Ipak, nasledni govornici u mešovitim grupama imaju i određene koristi: oni usavršavaju i proširuju svoj vokabular i jačaju pozitivnu ideju o svom naprednijem lingvističkom i kulturnom znanju španskog jezika (Blejk i Zajzik 2003: 541). 


\section{Rad u mešovitim parovima}

Radeći zajedno, govornici španskog kao SJ i kao naslednog jezika se dopunjuju i pomažu jedni drugima. Istraživanje u kome je analiziran zajednički rad parova sačinjenih od jednog stranog i jednog naslednog govornika na različitim zadacima na španskom jeziku pokazalo je da zadatke rešavaju u podjednakoj meri, te da je i jedna i druga grupa učenika svesna svojih jačih i slabijih strana u jeziku, prihvata razlike i koristi ih na najbolji način, smatrajući pozitivnom činjenicu da rade sa osobom koja ima drugačije jezičko okruženje (Bouls 2011: 53). U međusobnoj interakciji govornici kojima je španski SJ oslanjali su se na nasledne govornike što se tiče vokabulara i u manjoj meri gramatike. S druge strane, nasledni govornici su se, kod zadataka pisanja, oslanjali na svoje partnere što se tiče pravopisa, odnosno pisanja reči i akcenata (Bouls 2011). Međutim, prema analizi Bouls (2009), kada nasledni i strani govornici rade u mešovitim parovima i imaju usmenu interakciju, prvi pomažu drugima više nego obrnuto, što znači da pri zajedničkom radu više koristi imaju govornici SJ nego nasledni govornici.

Prvo istraživanje koje je poredilo parove naslednih i stranih govornika s jedne i parove stranih govornika u učionici s druge strane pokazalo je da se u zadacima sa usmenom interakcijom više govori u mešovitim parovima koji gotovo isključivo koriste ciljni (španski) jezik, dok parovi stranih govornika češće ubacuju svoj prvi jezik (engleski) u konverzaciju. Kako je svim učenicima u ovom ispitivanju engleski dominantni jezik, ova činjenica ne ukazuje na to da neki bolje poznaju engleski, već da postoje različita očekivanja u interakciji mešovitog naspram „stranog“" para (Bouls i dr. 2014: 512).

Prema istraživanju koje se ticalo modifikacije govora maternjih govornika upućenog nematernjim govornicima, maternji govornici se često nevoljno upuštaju u razgovor sa nematernjim govornicima. Za razvoj toka konverzacije između maternjih i nematernjih govornika važnu ulogu igra razumljivost nematernjih govornika. Kada je u razgovoru između maternjeg i nematernjeg govornika ovog drugog teže razumeti, prvi mora češće da pita za značenje kako bi se konverzacija nastavila. Istraživanje je pokazalo da maternji go- 
vornici manje govore u situacijama kada sagovornike često moraju da pitaju za značenje, a da su skloniji tome da ih ispravljaju (Gas i Varonis 1985: 42, 55).

\section{Predmet, cilj i metode istraživanja}

Predmet ovog istraživanja jeste analiza heterogenih grupa za učenje španskog jezika, koje čine govornici španskog kao stranog jezika, nasledni govornici španskog jezika, kao i maternji govornici. Ispitivanjem jezičkih navika ovih grupacija i njihovog stava prema radu u mešovitoj grupi i prema drugim kolegama nastojimo da zaključimo koje su prednosti i mane ovakvog učenja po učenike različitog jezičkog okruženja, zatim koliko se ovakvo učenje razlikuje od uobičajene nastave jezika i, najzad, da li bi učenici iz ovakvih grupa radije učili jezik $u$ homogenim grupama.

Istraživanje je sprovedeno među studentima osnovnih i master studija sa Katedre za romanistiku, smer hispanistika, na tri nemačka univerziteta: Univerzitet Humbolt u Berlinu, Slobodni univerzitet u Berlinu (FU, Frei Universität) i Univerzitet u Potsdamu. U ispitivanju su učestvovala 32 studenta različitog uzrasta i različitih nivoa studija (od prve godine osnovnih studija pa do mastera). Kako je za naše istraživanje bitniji nivo španskog jezika nego uzrast ili godina studija, nije predstavljalo problem to što su studenti različitih nivoa studija i različitog uzrasta. Naime, za studije hispanistike na ovim univerzitetima neophodno je imati predznanje iz španskog jezika na najmanje A2 nivou, te se može reći da ispitanici uče španski jezik u grupama namenjenim za srednji i viši nivo, dok početnika nema (što se može zaključiti i po odgovorima koji su napisani isključivo na španskom jeziku).

Važno je istači da broj ispitanika (32) ne predstavlja idealno polazište za kvantitativnu analizu, uzimajući u obzir činjenicu da su ispitanici u jednom bloku pitanja razvrstani na dve grupe. Međutim, anketa je upotpunjena otvorenim pitanjima na koja su ispitanici mogli slobodno da odgovaraju, pa je metoda analize kombinovanog tipa jer spaja tumačenje kvantitativne i kvalitativne metode, zbog čega se 
dobija bolji uvid $\mathrm{u}$ istraživani fenomen. Situacija po pitanju broja ispitanika je veoma slična većini konsultovanih istraživanja na temu učenja jezika u mešovitoj grupi jer je u tim radovima broj ispitanika u rasponu od 16 do 44 studenta, s tim što su ankete dopunjene intervjuima sa studentima-ispitanicima (Burgo 2016, Dones Erera 2015, Edstrom 2007).

Istraživanje je rađeno u vidu ankete na španskom jeziku koja kombinuje pitanja zatvorenog i otvorenog tipa. Anketa je napravljena u formi google upitnika i zahvaljujući dvema lektorkama sa Katedre za romanistiku na Univerzitetu Humbolt podeljena je studentima hispanistike preko platforme Moodle, a zatim je autorka rada podelila anketu preko Facebook grupa tri pomenuta univerziteta. Pre konkretnih pitanja ispitanicima je naznačeno da je anketa anonimnog karaktera i da se koristi za istraživanje u okviru master rada. Odgovori su prikupljeni u periodu između januara i marta 2018. godine.

Kao dodatni izvor podataka u vezi sa ovom temom urađen je intervju sa T. D, lektorkom na Univerzitetu Humbolt u Berlinu na katedri za Romanistiku. Ona predaje na kursevima latinoameričkog filma, istorije, kulture i društva latinoameričkih zemalja, a na master studijama drži časove budućim profesorima španskog jezika i koordiniše njihovu metodičku praksu u osnovnim i srednjim školama. U Institutu Servantes drži časove španskog jezika i kulture različitih hispanskih zemlja, a takođe je radila i kao profesorka prevođenja (nemački-španski). Rođena je u Madridu, gde je započela studije na Univerzitetu Komplutense, a diplomirala je hispanistiku i germanistiku na Slobodnom univerzitetu u Berlinu, gde živi već 30 godina.

Autorka rada je na Univerzitetu Humbolt pohađala jedan njen kurs namenjen studentima master studija, gde je određeni broj studenata bio hispanskog porekla. Posmatranjem međusobnog odnosa studenata i odnosa predavača prema njima rodila se ideja da bi intervju mogao dodatno da razjasni mnoge bitne aspekte učenja jezika u mešovitoj grupi, pogotovo uzimajući u obzir njenu ,jezičku i preseljeničku istoriju“. Intervju se sastojao iz osam pitanja koja su se ticala prisustva studenata različitog jezičkog okruženja u grupama, razlikâ između ovih studenata i njihovog zajedničkog rada. 


\section{Rezultati istraživanja}

Pre same analize rezultata ankete važno je predstaviti njenu strukturu. Prvu grupu pitanja čine pitanja opšteg karaktera i njihov cilj je određivanje detaljnijeg profila ispitanika (uzrast, pol, univerzitet, nivo studija, jezik koji se koristi u porodičnoj komunikaciji, dužina boravka u Nemačkoj, druga zemlja porekla pored Nemačke, ukoliko takva postoji, nivo kompetencije na nemačkom jeziku, jezik koji ispitanik smatra svojim dominantnim jezikom, kao i niz pitanja o korišćenju španskog jezika sa drugim ljudima). Druga grupa pitanja odnosi se na proces učenja i usavršavanja jezika (za vreme studija) i stav studenata prema španskom jeziku, što ima za cilj da uporedi ove stavke kod govornika španskog kao SJ s jedne strane i govornika španskog kao J1 sa druge. Pitanja su, konkretno, vezana za odabir najtežih i omiljenih segmenata u učenju jezika, kao i za način vežbanja i usavršavanja španskog jezika van fakulteta. Nakon ovoga slede pitanja koja utvrđuju kojoj grupi ispitanici pripadaju: gde su prvi put počeli da uče/ usvajaju španski jezik, gde su učili španski jezik pre fakulteta, kao i pitanje kojim se tražio njihov nedvosmislen potvrdni ili odrični odgovor: Da li je španski vaš maternji ili nasledni jezik? Do ovog, sva pitanja su bila namenjena svim ispitanicima, a ovo pitanje usmerava ispitanike na (1) govornike španskog kao SJ (ako odgovore sa "ne") i (2) nasledne i maternje (govornike španskog kao J1) (ukoliko je njihov odgovor "da“). Oni su potom, svako u svojoj „kategoriji“, odgovarali na različita pitanja (Likertova skala i pitanje otvorenog tipa) u vezi sa stavom prema prisustvu druge grupe studenata na časovima i zajedničkom radu sa njima.

Neophodno je i detaljnije predstaviti i razgraničiti profil ispitanika jer ovo istraživanje kombinuje odgovore tri različita profila. Od 32 ispitanika, za 23 studenta španski je strani jezik, što zaključujemo na osnovu negativnog odgovora na pomenuto pitanje $D a$ li je španski vaš maternji ili nasledni jezik ${ }^{1}$. Podela učesnika, među-

1 Pojam „nasledni jezik“ je u okviru ovog pitanja u anketi objašnjen na sledeći način: El término 'hablante de herencia' se refiere a las personas que adquirieron el español en casa, en familia y que tienen origen hispano pero crecieron en un país donde el español no es lengua oficial. 
tim, nije tako jednostavna jer je poreklo nekih ispitanika složeno. Očigledno je u nekim slučajevim teško odrediti granice, pogotovo uzimajući obzir da postoji više definicija naslednog jezika, te smo odlučili da, kao i u istraživanju koje je sprovela Edstrom (2007), maternje i nasledne govornike (govornike španskog kao J1) tretiramo kao jednu grupu i njihove odgovore razmatramo kao jednu celinu. Njih ima ukupno devetoro.

Sagledavajući rezultate ankete sprovedene sa studentima i odgovore lektorke na pitanja u okviru intervjua, mogu se izdvojiti određeni zajednički segmenti. Rezultati ocenjivanja različitih tvrdnji u anketi su kod ispitanika kojima je španski J1 usklađeniji i oni su složniji u svojim odgovorima, dok kod stranih govornika ima više razilaženja u odgovorima i češća su podeljena mišljenja na različite teme (što je i razumljivo s obzirom na to da njih ima znatno više i da je grupa heterogena). Iz ovoga zaključujemo da neke teme i pitanja, zapravo, zavise od pojedinaca, njihovog psihološkog sklopa, ličnih navika i izbora, a manje od okolnosti u kojima uče. Neminovno je, međutim, izvesti određene zaključke koji se tiču rada u ovakvim okolnostima, veoma drugačijim od učenja jezika u uobičajenim grupama sa učenicima koji imaju isti nivo poznavanja stranog jezika i isto kulturno okruženje.

Konverzacija je važan aspekt učenja stranog jezika i mnogima predstavlja problem. Međutim, prema rezulatima ankete konverzacija je među ispitanicima omiljena jezička aktivnost i aspekt koji stvara najmanje problema. Jedan od mogućih razloga za to je činjenica da su na časovima konstantno okruženi kolegama kojiima je španski J1, „upijaju“ pravilan izgovor i moraju da govore na španskom. Pored toga, najveći broj ispitanika usmenu produkciju vežba sa prijateljima i svi osim jednog ispitanika barem ponekad pričaju na španskom sa prijateljima. Ovo potvrđuje i konstatacija lektorke T.D. da zbog specifičnog sastava grupe studenti češće međusobno pričaju na španskom, ponekad i izvan učionice (što ističe i određeni broj učesnika kojima je španski J1). Takođe je značajan podatak da se većina stranih govornika (uz nekoliko izuzetaka) ne oseća nervozno kada treba da radi u grupi sa kolegama kojiima je španski J1 ili da govori na španskom pred njima. 
Prema rezultatima ankete, pripadnicima obe grupe je uglavnom svejedno sa kim će raditi kada su u pitanju grupni radovi, što znači da se tu slažu i da ne prave mnogo razlika međusobno. Ispitanici većinski učestvuju u radu grupe podjednako nezavisno od toga ko su drugi članovi, premda su izvorni/nasledni govornici usaglašeniji i odlučniji u ovoj tvrdnji.

Kada je ispravljanje grešaka u pitanju, ispitanicima iz obe kategorije ne smeta da ih drugi ispravljaju već su im zahvalni. Međutim, strani govornici većinski ne ispravljaju svoje kolege kojiima je španski J1, dok ovi to čine ponekad, što potvrđuju i odgovori na pitanja otvorenog tipa. Kako je ispravljanje grešaka važan segment u jezičkom sazrevanju, pogotovo uz privilegiju da student ima oko sebe veći broj govornika kojima je španski J1 i koji mogu lako ukazati na greške, zaključujemo da bi napredak bio značajno brži ukoliko bi se studenti međusobno više ispravljali, pogotovo zato što im to ne predstavlja problem.

Na osnovu sprovedenog intervjua i anketnih odgovora kako ispitanika kojiima je španski J1, tako i onih kojiima je španski SJ, može se reći da rad u mešovitoj grupi sa studentima iz različitog jezičkog okruženja donosi višestruke koristi, pre svega stranim govornicima. I intervju i anketa su nedvosmisleno potvrdili da studenti i predavači raznolikost i raznovrsnost smatraju vrlo pozitivnom stavkom koja obogaćuje nastavu i svakog pojedinca na ličnom nivou. T.D. je u okviru intervjua istakla da studenti kojima je španski J1 donose iskustva iz svoje zemlje porekla i stranim govornicima prenose svoju kulturu, ali doprinose i svojim naglascima i različitom leksikom. U anketi je veći broj stranih studenata takođe istakao ove stavke: i za njih kolege hispanskog porekla predstavljaju model po pitanju jezika, a svi ispitanici kojiima je španski J1 se apsolutno slažu sa tvrdnjom da im je drago što svojim kolegama stranim govornicima mogu da prenesu hispansku kulturu i tradiciju, dok većini učenje u ovakvim grupama pomaže da se lakše naviknu i prepoznaju različite dijalekte španskog jezika. Neki učesnici kojima je španski J1 vide za sebe prednosti rada u mešovitoj grupi jer više razmišljaju o jeziku, svesniji su njegove upotrebe i daju jasnije i razloženije odgovore, što je i T.D. navela u svom odgovoru. Svi vide manje negativnih 
strana ovakvog učenja, pa je lektorka navela samo jednu stavku - to što neki učenici previše pričaju pa je drugima teže da dođu do reči od njih, a isto je primetila i jedna ispitanica u anketi.

Imajući u vidu upadljivo povećavanje broja govornika španskog jezika na svim nivoima, učenje (španskog) jezika u mešovitim grupama sa stranim, naslednim i u nekim slučajevima maternjim govornicima trebalo bi i dalje istraživati, tražeći odgovore na ovde navedena ali i na neka druga pitanja. Veći broj učesnika (iz sve tri kategorije) ili npr. dodatno intervjuisanje ispitanika doprineli bi znatno relevantnijim rezultatima.

\section{Zaključak}

Slučajevi gde različite vrste govornika (strani, nasledni, a nekada i maternji) uče španski jezik zajedno nisu tako retki i predstavljaju jedinstvenu okolnost za jezičko obrazovanje koja se veoma razlikuje od standardne nastave jezika organizovane po nivoima. $\mathrm{Na}$ osnovu sprovedenog istraživanja i rezultata ranijih istraživanja zaključujemo da učenje jezika u grupi gde su prisutni strani, nasledni (i maternji) govornici ima mnogo više prednosti nego nedostataka, pogotovo za pripadnike prve grupe. Kao prednosti najčešće se ističu bliži dodir sa drugom kulturom i različitim dijalektima, zatim autentičan jezik kojem su strani govornici izloženi, kao i raznovrsnost koju studenti smatraju umnogome pozitivnom i korisnom, kako za jezičko, tako i za lično sazrevanje. Uzajamna pomoć je takođe važna stavka u ovakvim grupama jer sve vrste govornika imaju svoje specifičnosti i slabije strane koje treba razvijati: naslednima uglavnom slabije ide pisanje, maternji govornici treba da rade na argumentovanju i gramatičkim objašnjenjima, a strani, između ostalog, na izgovoru i vokabularu, pa se tako međusobno dopunjuju. Značajno je da je većina istraživanja pokazala da stranim govornicima uglavnom nije neprijatno kada treba da govore na španskom pred naslednim i maternjim govornicima (uz određene izuzetke).

Za razliku od nekih drugih istraživanja (npr. Dones Erera 2015), gde ispitanici takođe vide prednost ovakvog rada ali bi radije učili 
jezik samo sa onima koji imaju nivo približan njihovom, ovo istraživanje je pokazalo da najveći broj ispitanika ne misli da bi učenje jezika u uobičajenim okolnostima bilo lakše, već zastupaju suprotnu tvrdnju. Veoma je značajan podatak da su svi ispitanici kojima je španski J1 odgovorili na ovaj način, dok su i gotovo svi iz druge grupe ispitanika rekli da bi radije učili španski jezik kao i do sada. S obzirom na specifičnost ovakvih grupa i različite potrebe studenata, na profesorima je veliki zadatak i izazov da na času uspostave ravnotežu, posvete dovoljno pažnje svim učenicima i podstaknu ih da učestvuju jednako kako bi svi imali koristi i dobili ono što im je potrebno za napredak.

\section{LITERATURA}

Akosta Korte 2009: Acosta Corte, Á. (2009). Hijos de hispanohablantes en el exterior: el desarrollo lingüístico de hablantes de herencia que adquieren el español rodeados de otros idiomas, Selección de artículos del I Congreso de Español como Lengua Extranjera en Asia-Pacífico (CE/LEAP). Manila: Instituto Cervantes de Manila y Embajada de España en Filipinas. 131-144.

Blejk i Zajzik 2003: Blake, R. J. \& Zyzik, E. C. (2003). Who's Helping Whom?: Learner/Heritage-Speakers' Networked Discussions in Spanish, Applied linguistics, 24(4), 519-544.

Bouls 2009: Bowles, M. A. (2009). Task-based interactions of L2-heritage learner pairs in Spanish language classrooms, The Modern Language Journal.

Bouls 2011: Bowles, M. A. (2011). Exploring the role of modality: L2heritage learner interactions in the Spanish language classroom, Heritage Language Journal, 8(1), 30-65.

Bouls i dr. 2014: Bowles, M. A, Adams R. J. \& Toth P. D. (2014). A comparison of L2-L2 and L2-heritage learner interactions in Spanish language classrooms, The Modern Language Journal, 98(2), 497-517.

Bugarski 2003: Bugarski, R. (2003). Jezici. Beograd: Čigoja štampa : XX vek. Burgo 2016: Burgo, C. (2016). Perceptions of L2 Spanish learners in the mixed classroom, Revista Nebrija de Lingüística Aplicada, (20).

Dones Erera 2015: Dones-Herrera, V. (2015). Heritage vs. Non-heritage Language Learner Attitudes in a Beginning-Level Mixed Spanish Language Class. A Thesis presented in Partial Fulfillment of the 
Requirements for the Degree Spanish Master in Arts, Arizona State University. (dostupno na: https://lib.asu.edu)

Edstrom 2007: Edstrom, A. (2007). The mixing of non-native, heritage, and native speakers in upperlevel Spanish courses: A sampling of student opinion, Hispania, 90(4), 755-768.

Gas i Varonis 1985: Gass, S. M. \& Varonis, E. M. (1985). Variation in native speaker speech modification to non-native speakers, Studies in Second Language Acquisition, 7(1), 37-57.

Jovanović i Vučina Simović 2012: Jovanović, A. i Vučina Simović, I. (2012). Odlike i potrebe nastave srpskog kao zavičajnog jezika, u: M. Kovačević (ur.), Srpski jezik, književnost, umetnost: zbornik radova sa VI međunarodnog skupa održanog na Filološko-umetničkom fakultetu u Kragujevcu, Kragujevac: FILUM, 383-395.

Kamens 2001: Cummins, J. (2001). Bilingual Children's Mother Tongue: Why IsIt Important for Education?, Sprogforum, 7(19), 15-20.

Kondo-Braun 2005: Kondo-Brown, K. (2005). Differences in language skills: Heritage language learner subgroups and foreign language learners, The Modern Language Journal, 89(4), 563-581.

Potovski 2002: Potowski, K. (2002). Experiences of Spanish heritage speakers in university foreign language courses and implications for teacher training, ADFL Bulletin, 33(3), 35-42.

Vučo 2015: Vučo, J. (2015). Kako do srpskog kao naslednog, u: M. Kovačević, J. Petković (ur.), Srpski jezik od Vuka do danas: zbornik radova sa IX međunarodnog naučnog skupa održanog na Filološko-umetničkom fakultetu u Kragujevcu, Knjiga I, Kragujevac: FILUM, 435-441.

\section{IZVORI SA INTERNETA}

Institut Servantes 2017: El español: una lengua viva. Informe 2017, Madrid: Instituto Cervantes. (dostupno na:

https://cvc.cervantes.es/lengua/espanol_lengua_viva/pdf/espanol lengua viva 2017.pdf)

Kraljevski Dekret 1027/1993. (1993). Real Decreto 1027/1993. Boletín del Estado. (dostupno na: http://www.boe.es/buscar/pdf/1993/ BOE-A-1993-20613-consolidado.pdf)

UCLA 2001: UCLA Steering Committee, Heritage Language Research Priorities Conference Report, Los Angeles: University of California. (dostupno na: http://www.cal.org/heritage/involved/ hlprioritesconf00.pdf) 


\title{
Anđela Gašić
}

\section{LA DINÁMICA DEL GRUPO CON LOS ESTUDIANTES DE ESPAÑOL COMO LENGUA DE HERENCIA, EXTRANJERA Y MATERNA}

\begin{abstract}
Resumen
Las necesidades y los enfoques en la enseñanza de hablantes de herencia son distintos en comparación con la enseñanza de una lengua extranjera. Sin embargo, dado que esa área no recibe suficiente atención, no es inusual que los hablantes de herencia aprendan español en un contexto formal en grupos mixtos junto con aprendices de ELE, y en algunas ocasiones incluso con hablantes nativos. La parte investigadora del trabajo está compuesta por el análisis de una encuesta sobre el aprendizaje en grupos heterogéneos y la relación entre los tres grupos de estudiantes anteriormente mencionados. La encuesta fue realizada por estudiantes de Filología Hispánica de tres universidades alemanas, donde los grupos son significantemente mixtos debido al gran número de inmigrantes hispanohablantes en el país. Asimismo, a la investigación se incorpora la entrevista con la lectora T.D. del departamento de Filología Románica de la Universidad Humboldt sobre el trabajo de los estudiantes en grupos mixtos. Los resultados de la investigación han mostrado que el aprendizaje en grupos mixtos tiene múltiples ventajas y pocas desventajas para los estudiantes, que están conscientes de ese hecho y no elegirían estudiar español en circunstancias comunes y distintas a lo que ellos están acostumbrados.
\end{abstract}

Palabras clave: hablantes de herencia, estudiantes de español como lengua extranjera, hablantes nativos, enseñanza de la lengua española, enseñanza en grupos heterogéneos 